\title{
The Effect of 8 Weeks of Aerobic Exercise on Serum Lipids and Kidney Function in Middle-Aged T2DM Patients
}

\author{
Cheol-Woo Kim', Yi-Sub Kwak', Gun-Do Kim² and Young-\| Kim* \\ ${ }^{1}$ Department of Physical Education, Dong-Eui University, Busan 604-714, Korea \\ ${ }^{2}$ Department of microbiology, Pukyong University, Busan 608-737, Korea \\ ${ }^{3}$ Department of Sports \& Health Management, Youngsan University, Yangsan 626-790, Korea
}

Received December 12, 2011 /Revised January 17, 2012 / Accepted January 26, 2012

\begin{abstract}
The purpose of this study was to examine the effect of 8 weeks of aerobic exercise on serum lipids and kidney function in middle-aged T2DM patients. Subjects participated in aerobic exercise training during 8 wk. They started with an exercise intensity of $\mathrm{HR}_{\max } 60-75 \%, 20 \sim 45$ minutes per day, 3 5 times a week. The results were compared to the baseline after 8 weeks. After the 8 -week aerobic exercise routine, the body fat percentage and fasting glucose were significantly decreased, and the total cholesterol (TC) andtriglycerides (TG) were significantly decreased. Additionally, kidney function (Blood Urea Nitrogen (BUN], uric acids, and creatinine) was not significantly changed. In conclusion, a regular 8-week aerobic exercise training routine may improve serum lipids; however, kidney function (BUN, uric acids, and creatinine) did not change in middle-age type 2 diabetes mellitus (T2DM) and T2DM in diabetic nephropathy patients.
\end{abstract}

Key words : Aerobic exercise training, serum lipids, kidney function, type 2 diabetes mellitus (T2DM)

\section{서 론}

당뇨는 심각한 대사적 질환이며 유병률은 세계적으로 점차 증가하는 추세이다. 2000년에는 전체적으로 1 억 7천만 명이며, 다가올 2030년에는 3억 6천만 명을 넘을 것으로 추측된다[17]. Jeong 등[7]의 당뇨 합병증 보고에 의하면 3개의 종합병원 과 보건소를 200명을 대상으로 설문을 통하여 당뇨를 가지고 있으면서 미세혈관합병증을 동반한 인원은 63 명 $(31.5 \%)$ 을 나 타났고, 눈은 51명(25.5\%), 신장은 25명 $(12.5 \%)$, 발의 합병증은 23 명 $(11.5 \%)$ 으로 나타냈다.

이렇듯 당뇨환자에서 빈번히 나타나는 합병증은 자율신경 병증과 신증(naturopathy) 및 산화적 스트레스로 인한 간 기능 의 저하이며, 망막증의 발병 원인에는 당뇨 신증과 자율신경 병증이 관련된다.

고혈당으로 인해 약해진 신장 기능은 신장의 과기능과 과여 과를 유도하여 사구체 여과계를 손상시키는 주요인자이며[6] 당뇨병성 신증(diabetic naturopathy)은 type 1에서 40 50\%, type 2 에서는 약 $10 \sim 37 \%$ 발병되는 것으로 나타났다[2].

현재까지 신장 기능에 관한 연구는 정상인[4,10,18]과 동물 [9]을 대상으로 한 일회성 운동에 관한 것이 대부분이며 특히 제 2형 당뇨(T2DM) 환자를 대상으로 운동이 신장 기능에 영 향을 미치는지에 대한보고는 미흡한 실정이며 더구나 당뇨성 신증 환자를 대상으로 운동의 효과를 제시한 연구와 보고는

*Corresponding author

Tel : +82-55-380-9441, Fax : +82-55-380-9352

E-mail : kyi0234@ysu.ac.kr
전무 실정이다.

따라서 본 연구의 목적은 첫째, 8 주 규칙적인 운동 트레이닝 에 따른 제 2형 당뇨(T2DM) 환자의 신체조성과 혈청지질 변 화 기능을 파악하는 것이며 둘째, 제 2형 당뇨(T2DM) 환자 및 당뇨 신증(diabetic naturopathy)을 가진 환자의 1 예를 통하 여 규칙적인 운동이 신장 기능에 영향을 미치는지에 대하여 보고하고자 한다.

\section{재료 및 방법}

\section{연구대상}

본 연구는 $Y$ 대학병원 내과(당뇨 클리닉)에 내원하는 제 2형 당뇨 환자(T2DM) 남자 3 명과 당뇨성 신장질환으로 판정된 중년 여성 피험자 1 명을 포함하여 총 4 명을 대상으로 실시하 였다. 8주 운동프로그램은 모두 자발적 참여 의사를 밝히는 대상자들로 하였으며, 의학적 검진(문진과 혈액검사)를 통하 여 제 2형 당뇨(T2DM) 이외 합병증을 파악하였다. 총 4 명의 피험자 중, 제 2형 당뇨 이외 합병증을 가진 대상자는 고협압 1 명(남), 동맥경화 1 명(남), 당뇨 신증 1 명(여)이며 질병 관련하 여 약물을 복용하는 자는 3명이었다(Table 2).

\section{실험 절차}

\section{체지방 측정}

체지방 측정은 체지방측정계(model 310, biodynamics, USA)를 통하여 피험자가 누운 상태에서 우측 손등과 손목, 우측 발등과 발목에 전극 4 개를 부착하고 손등과 발등에 고주 
파(500 KHZ) 정전류 $(1 \mathrm{~mA})$ 를 계속해서 흘려주고 손목과 발목 간의 임피던스를 측정하여 체지방률을 구하는 방법으로 시행 하였다.

\section{안정시 심박수와 안정시 혈압 측정}

안정시 심박수와 혈압은 편안이 앉은 자세로 측정 30 분 안 정을 취한 후 자동혈압계(COLIN, model BP-203 RVII)로 측정 되었다.

\section{최대하 운동부하검사 및 8 주 걷기 운동프로그램}

최대하 운동부하검사는 운동부하를 점진적으로 증가시키 는 Bruce (1973)의 방법으로 시행하였고 최고산소섭취량 측정 은 연령별 예측 $\mathrm{VO} 2 \mathrm{max}$ 의 $80 \%$ 해당되는 목표심박수(THR) 에 도달할 때와 자신이 운동검사를 지속하지 못할 시점을 선 택하였다. 운동중 심장이상을 파악하기 위해서 Stress test monitor (Model Q4500, Quinton, USA)를 사용하였고 최고산 소섭취량 측정은 자동화 가스분석기(Quinton metabolic cart, USA)를 사용하여 측정하였다.

유산소운동프로그램의 운동형태는 트레드밀 걷기 8 주간 구 성하였고, 운동강도는 각 피험자들의 운동부하 검사에서 측정 한 최대심박수 $\left(\mathrm{HR}_{\max }\right)$ 을 바탕으로 $60 \sim 75 \%$ 의 설정하였고 처 음 1 2주 프로그램은 초기훈련기(60 65\%)로 정하고, 다음 3-8 주 프로그램은 향상훈련기(65 75\%), 운동시간은 운동을 처음 시작하는 초기훈련기에는 20 분, 향상훈련기에는 30 45분으로 실시하였다. 운동 빈도는 주 3 5회 실시하였다(Table 1).

\section{혈액 분석}

약 12 시간 정도 공복상태를 유지하도록 한 후, 혈액은 $Y$ 대학병원의 임상병리과에서 헤파린으로 처리된 일회용 주사 기를 사용하여 상완정맥(anttcubital vein)에서 22gage needle 을 사용하여 총 $15 \mathrm{ml}$ 를 채혈하였다.

BUN 측정은 a-GentTMBUN reagent (ABBOTT LABORATORIES, Diagnostics Division, USA)를 사용하여 효 소법을 사용하였다, 혈청요산(Uric acide)은 uricase법으로 측 정였고Creatinine은 Gilchem TM Creatinin reagent(Gilford Giagnostics, USA)를 사용하여 측정하였다.

총 콜레스테롤(total cholesterol, TCH)은 BM/Hitachi 747 을 이용하여 효소법에 의해 측정하였으며, 중성지방(triglyceride, TG)은 비색정량법(colirimetry)에 의해서 측정하였다. 고밀도 지단백 콜레스테롤(high density lipoprotein cholesterol, HDL-C)의 측정은 Abbott HDL method 이용하였으며, 상등액에서 T· CHO-S · R1을 이용한 효소법으로 측정하였 다. 저밀도 지단백 콜레스테롤(low density lipoprotein cholesterol, LDL-C)은 LDL=TCH-HDL-TG/5로 구하였다.

\section{통계 분석}

본 실험의 결과는 SPSS 통계 package (ver 12.0)을 이용하여 각각의 실험에 따른 요인들의 변화를 알아보기 위해 기술통계 량(평균과 표준편자)를 산출하고 8 주 유산소 운동프로그램 적 용 전·후의 신체조성 및 콜레스테롤, 신장기능의 변화를 알 아보기 위해 대응분석(Paired t-test)을 통해 통계적 유의수준 0.05 로 검증하였다.

\section{결과 및 고찰}

\section{신체적 특성}

제 2형 당뇨집단의 신체적 특성은 Table 2에서 나타냈다. 체지방률(\%body fat)과 공복시 혈당(fasting glucose), 안정시 심박수(HRrest)와 최고산소섭취량(peak $\mathrm{VO}_{2}$ )은 8 주 트레이닝 전에 비해 트레이닝 후 유의하게 $(p<0.05)$ 감소하였다. 그러나 체중, BMI, 안정시심박수(HRrest) 혈압(blood pressure)은 감 소함을 나타냈지만 통계적으로 유의한 차이를 나타내지 못했 다(Table 2). 이는 제 2형 당뇨(T2DM)에서 대표적인 운동의 효과를 나타낸 것이라 사료되며 이전의 연구들 $[5,14,16]$ 에서도 비슷한 경향을 나타내고 있다

\section{8주 유산소 트레이닝 전, 후 콜레스테롤}

제 2형 당뇨집단의 신체적 특성과 혈청지질은 Table 2에서 나타냈다.

대상자의 혈청지질 중 중성지방(TG)과 총콜레스테롤(total cholesterol)은 유의하게 $(p<0.05)$ 감소하였다. 하지만 고밀도지 단백(HDL-C), 저밀도지단백(LDL-C)은 감소함을 나타냈으나 통계적으로 유의한 차이는 나타내지 못했다.

혈청지질은 제 2형 당뇨에서 심혈관계질환(CVD) 위험과 운동능력(exercise capacity)을 저해하는 위험요소 중의 하나 이며[8], 규칙적인 운동 트레이닝을 통해 혈청지질이 감소된 연구는 선행연구들에서 잘 나타나 있다[14,15,16]. Lee 등[13] 은 신장 질환자를 25 명을 대상으로 12 주간(주 3 회, 회당 30 분) 트레이닝 시켜 유연성 및 근력 등이 유의하게 향상된 것을 나타냈으며 혈청지질의 감소와 혈액변인에 긍정적인 변화를 나타냈다. 또한 Spellman [15]의 보고에 의하면 3개월의 의학 적 치료 및 운동으로 체중이 감소하고 혈청지질의 저밀도 지 단백(LDL-C)은 $12 \sim 18 \%$ 감소함을 나타냈다.

8주 유산소 트레이닝 전, 후 신장기능

제 2형 당뇨집단의 신장 기능은 Table 2와 Table 3에서 나타

Table 1. 8 week aerobic exercise training program

\begin{tabular}{cccc}
\hline Exercise duration & Exercise intensity & Exercise time & Exercise frequency \\
\hline $1-2 \mathrm{wk}$ & $60-65 \% \mathrm{HR}_{\max }$ & $20 \mathrm{~min}$ & $3-5$ \\
$3-8 \mathrm{wk}$ & $65-75 \% \mathrm{HR}_{\max }$ & $30-45 \mathrm{~min}$ & $\mathrm{Rep} / \mathrm{wk}$ \\
\hline
\end{tabular}


Table 2. Comparison of characteristics baseline and 8weeks exercise training

\begin{tabular}{|c|c|c|c|c|}
\hline Groups & Baseline & $8 \mathrm{wk}$ & T-value & P-value \\
\hline \multicolumn{5}{|l|}{ Subjects of characteristic } \\
\hline Age (yr) & \multicolumn{2}{|c|}{$51.2 \pm 11.0$} & - & NS \\
\hline Height (cm) & \multicolumn{2}{|c|}{$165.2 \pm 5.12$} & - & NS \\
\hline Weight $(\mathrm{kg})$ & $66.7 \pm 2.06$ & $65.2 \pm 4.11$ & 1.260 & 0.297 \\
\hline Fat $(\%)$ & $25.3 \pm 2.83$ & $19.1 \pm 1.25$ & 5.333 & $0.013^{*}$ \\
\hline BMI & $24.4 \pm 0.88$ & $23.8 \pm 1.02$ & 1.207 & 0.314 \\
\hline Fasting Glucose $(\mathrm{mg} / 100 \mathrm{ml})$ & $172.2 \pm 59.6$ & $148.7 \pm 50.9$ & 3.710 & $0.034^{*}$ \\
\hline \multicolumn{5}{|l|}{ Heart rate \& Exercise capacity } \\
\hline Rest HR (beats/min) & $75.2 \pm 16.6$ & $70.2 \pm 13.0$ & 1.568 & 0.215 \\
\hline Rest SBP $(\mathrm{mmHg})$ & $128.0 \pm 12.0$ & $126.2 \pm 11.0$ & 1.481 & 0.235 \\
\hline Rest DBP (mmHg) & $87.5 \pm 9.57$ & $85.0 \pm 10.0$ & 1.000 & 0.391 \\
\hline Peak VO2 $(\mathrm{ml} / \mathrm{kg} / \mathrm{min})$ & $22.6 \pm 4.39$ & $28.0 \pm 5.22$ & -2.284 & 0.107 \\
\hline \multicolumn{5}{|l|}{ Serum lipid } \\
\hline Total cholesterol (mg/dl) & $244.2 \pm 45.7$ & $195.2 \pm 31.3$ & 3.456 & $0.041^{*}$ \\
\hline Triglyceride $(\mathrm{mg} / \mathrm{dl})$ & $296.2 \pm 284.8$ & $253.7 \pm 279.9$ & 5.023 & $0.015^{*}$ \\
\hline HDL-C (mg/dl) & $37.2 \pm 10.9$ & $34.7 \pm 11.2$ & 0.666 & 0.553 \\
\hline LDL-C (mg/dl) & $126.2 \pm 77.8$ & $89.7 \pm 48.8$ & 1.263 & 0.296 \\
\hline \multicolumn{5}{|l|}{ Kidney function ( $\mathrm{n}=3$, Male) } \\
\hline BUN (mg/dl) & $17.2 \pm 2.60$ & $16.6 \pm 3.72$ & 0.166 & 0.883 \\
\hline Creatinine $(\mathrm{mg} / \mathrm{dl})$ & $0.86 \pm 0.05$ & $090 \pm 0.10$ & -1.000 & 0.423 \\
\hline Uric acid & $5.00 \pm 1.12$ & $5.33 \pm 0.72$ & -0.594 & 0.613 \\
\hline \multicolumn{5}{|l|}{ Complication } \\
\hline Hypertension & $1 / 4$ & & & \\
\hline Arthrosclerosis & $1 / 4$ & & & \\
\hline Diabetic nephropathy & $1 / 4$ & & & \\
\hline Diabetes duration & $3.33 \pm 1.52$ & & & \\
\hline \multicolumn{5}{|l|}{ Drug does } \\
\hline Yes & $3 / 4$ & & & \\
\hline No & $1 / 4$ & & & \\
\hline
\end{tabular}

Values are mean \pm S.D

냈다.

신장의 기능은 체액중의 과잉된 수분이나 전해질, 요소 등 의 노폐물을 걸러내어 배출함으로써 일정한 범위 내에서 유지 되도록 하며, 당뇨 신증의 경우 고혈당과 비효소적 당화단백, protein kinase $\mathrm{C}$ 의 유도, $\mathrm{ROS}$ 생성증가, prostaglandin 합성 이 당뇨병성 신증을 일으키는 주요 원인이다[3].

신장 기능의 평가 요인으로는 혈중 요소질소(blood urea nitrogen, BUN)와 크레아티닌(creatintine, $\mathrm{Cr}$ ), 요산(uric acids)을 들 수 있으며 요소질소(BUN)는 신장의 사구체에서 배설되고 그 중 일부가 세뇨관에서 제 흡수되며 요소질소 $(\mathrm{BUN})$ 의 농도는 신장혈관의 혈액순환과 기능에 관련이 있다. 또한 혈청 요산(Uric acid)은 대사적인 문제와 병인학적 (ethological) 위험요소(고혈압, 고지혈증, 고인슐린혈증, 산화
적 스트레스)로 확립되었다[8].

운동이 정상인에서 신장 기능에 미치는 연구중 일회성 운동 을 살펴보면 $\mathrm{Kim}[10]$ 은 장거리 일회성 운동이 혈청 크레아틴 (Creatine)과 요소질소(BUN)에 미치는 영향에 대해 연구하였 는데 운동직후에 모두 증가하다 회복기에 안정시 수준으로 돌아왔으며 $\mathrm{Kim}$ [9]의 보고에서는 STZ 당뇨 쥐를 대상으로 고강도(트레드밀 $0 \%, 25 \mathrm{~m} / \mathrm{min}$ )와 중강도(트레드밀 $0 \%, 8$ $\mathrm{m} / \mathrm{min}$ )로 나누고 4 주(주5회, 30 분)간 운동시킨 후의 신장조 직과 크레아틴(Creatine), 요소질소(BUN)의 변화는 대조군 그 룹에 비해 당뇨그룹에서 신장조직의 병리적 손상이 나타났으 며 저강도 그룹에서 보다 고강도 그룹에서 신장 기능이 손상 된 것을 나타냈다. 이는 혈청 크레아틴(Creatine)과 요소질소 $(\mathrm{BUN})$ 가 일회성의 중강도나 조금 강한운동 후에는 변화를 나 
Table 3. Kidney function of diabetic nephropathy (1 subject, woman)

\begin{tabular}{lcc}
\hline Variable & Baseline & $8 \mathrm{wk}$ \\
\hline Kidney function & & \\
BUN $(\mathrm{mg} / \mathrm{dl})$ & 56.3 & 69.8 \\
Creatinine $(\mathrm{mg} / \mathrm{dl})$ & 5.2 & 5.3 \\
Uric acid & 7.3 & 8.8 \\
\hline
\end{tabular}

타내지 않았으며[12], 단기간의 강한 운동직후[14], 마라톤의 지구성 운동후 며칠 동안 높아져 있음을 나타냈다[11]. 이러한 이유는 단기간의 고강도 운동은 외상과 단백질의 이화작용 (catabolism), 인체조직 단백질의 퇴화를 나타낸 것으로 이러 한 부산물의 방출로 신장의 능력을 초과한 것을 나타냈다[14]. 또한 규칙적인 운동이 신장기능에 미치는 효과를 규명한 연구를 살펴보면 Choi [1]는 동물을 대상으로 8주간 트레드밀 운동으로 당뇨 쥐의 신장사구체, 췌장의 랑게한스섬, 간세포 등의 형태학적 손상이 지연되었다고 보고하였고, Spellman [15]의 case study에 따르면 당뇨환자의 높아져 있는 안정시 요소질소(BUN) 수치는 3개월의 약물, 식이 및 낮은 강도의 운동 트레이닝으로 요소질소(BUN)를 정상 기준치로 회귀한 것을 보고하였지만 이것이 약물 및 식이로 인한 효과인지 운 동의 중재효과 인지는 명확하게 증명하지 못했다.

이상의 연구를 정리해보면 일회성 운동에서는 단시간 고강 도운동은 신장기능에 부정적 영향을 미치는 것으로 나타났으 며 규칙적인 식이와 약물복용, 운동요법에서는 신장기능에 긍 정적인 영향을 미친 것으로 나타났다[15].

본 연구에서는 8 주간 유산소 운동이 제 2형 당뇨환자 (T2DM)의 신체조성과 콜레스테롤은 감소시키는 데는 효과가 있었지만 당뇨 신증(diabetic naturopathy)을 가진 환자의 1예 에서의 크레아티닌(creatinine)과 요소질소(BUN), 요산(uric acid)에는 영향을 미치지 못했다(Table 3). 이러한 이유는 이전 의 보고[15]와 비교했을 시, 운동기간(8주)이 충분하지 못한 점과 운동중재 효과를 명확히 나타낼 수 있는 연구 디자인(세 분화된 대상자와 피험자 수, 다양한 운동강도의 제시) 부재로 사료된다. 하지만 아직까지 당뇨 신증의 관련연구가 부족한 점을 볼 때, 본 결과보고가 의미 있다 사료되며 추후 당뇨 신증 환자를 대상으로 한 운동과 관련된 다양한 시도가 필요 시 된다.

\section{결 론}

결과적으로 본 연구에서 8 주 유산소 운동 트레이닝은 제 2형 당뇨(T2DM)환자의 신체적 특성 및 혈청지질에 긍정적인 영향을 미친 것으로 나타났으나, 제 2형 당뇨(T2DM)환자 및 당뇨 신증 환자의 신장기능 개선에는 영향을 미치지 못했다. 따라서 제 2형 당뇨(T2DM)환자의 신장 기능을 증진시키는
데 있어 운동의 효과는 아직까지 명확하지 않다. 또한 당뇨 신증 환자의 운동효과를 증명할 세분화된 운동강도와 빈도가 필요하며 신장기능(형태 및 조직학적) 결과 제시가 필요하다.

\section{감사의 글}

본 논문은 영산대학교 교내연구비 지원에 의하여 연구 되었 음.

\section{Referenes}

1. Choi, D. G. 2004. Effects of regular walking and dietary on the weight, blood glucose, insulin sensitivity, and cell's morphology in the pancreas, kidney, liver of streptozotocin -diabetic rats, and activities of antioxidant enzymes. Department of physical education Graduate School, Kyung-Hee University, Seoul, Korea.

2. Choi, Y. K. and Lee, T. H. 1995. Diabetics and hyperlipidermia. pp. 111-113, Medical press, Seoul Korea.

3. Derubertis, F. R. and Craven, P. A. 1994. Activation of protein kinase $\mathrm{C}$ in glomerular cells in diabetes. Mechanism and potential links to the pathogenesis of diabetic glomerulopathy. Diabetes 43, 1-8.

4. Han, H. J. 2004. The effect of 12 weeks endurance exercise training on carriers in blood. Exercise Science 13, 15-24.

5. Hatunic, M., Finucane, F., Burns, N. Gasparro, D. and Nolan, J. J. 2007. Vascular inflammatory markers in early-onset obese and type 2 diabetes subjects before and after three months' aerobic exercise training. Diab. Vasc. Dis. Res. 4, 231-234.

6. Herman, W. H. and Greene, D. A. 1996. Microvascular complications of diabetes. In Haire-Joshu, D. (ed.), Management of diabetes mellitus perspectives of care across the life span (2nd eds.), pp. 232-280, St. Louis, MO: Mosby.

7. Jeong, I, S., Gill, G. S., Shin, Y. S., Kim, Y. S. and Lee, S. Y. 2006. Diagnosis-related characteristic of microvascular complications patients with type 2 diabetes mellitus. J. Kor. Acad Fam Med 27, 456-462.

8. Kadoglou, N. P., Iliadis, F., Angelopoulou, N., Sailer, N., Fotiadis, G., Voliotis, K., Vitta, I., Liapis, C. D. and Alevizos, M. 2008. Cardiorespiratory capacity is associated with favourable cardiovascular risk profile in patients with Type 2 diabetes. J. Diabetes Complications 22, 1-7.

9. Kim, J. O. 2004. Effect of exercise intensity on function \& morphological changes in kidney of streptozotocin-induced diabetic rat. Korean Sport Res. 15, 1007-1016.

10. Kim, S. H. 2002. Effect of renal function on distance running. Korean J. Physical Edu. 41, 351-362.

11. Klapcińska, B., Iskra, J., Poprzecki, S. and Grzesiok, K. 2001. The effects of sprint (300 m) running on plasma lactate, uric acid, creatine kinase and lactate dehydrogenase in competitive hurdlers and untrained men. J. Sports Med Phys. Fitness 241, 306-311. 
12. Lamont, L. S., Lemon, P. W. and Bruot, B. C. 1987. Menstrual cycle and exercise effects on protein catabolism. Med Sci. Sports Exerc. 19, 106-110.

13. Lee, Y. K., Kim, C. J., Pyo, H., Kim, C. H. and Ji, J. W. 2001. Endurance exercise training before hemodialysis : An effective therapeutic modality for end-stage renal disease patients. Korean J. Physical Nephrol. 20, 290-297.

14. Mashiko, T., Umeda, T., Nakaji, S. and Sugawara, K. 2004. Effects of exercise on the physical condition of college rugby players during summer training camp. Br. J. Sports Med 38, 186-190.

15. Spellman, C. W. 2008. Aggressively managing type 2 diabetes mellitus, hyperlipidemia, and bone loss. J. Am
Osteopath Assoc. 108, S20-27.

16. Svacinová, H., Nováková, M., Placheta, Z., Kohzuki, M., Nagasaka, M., Minami, N., Dobsák, P. and Siegelová, J. 2008. Benefit of combined cardiac rehabilitation on exercise capacity and cardiovascular parameters in patients with type 2 diabetes. Tohoku J. Experimental Medicine 215, 103-111.

17. World Health Organization. 2007. Prevalence of diabetes worldwide page. Available at: www.who.int/diabetes /facts/world_figures/en.

18. Yoon, W. S., Shin, E. L. and Park, D. H. 2001. Effect of the prolonged oral creatin supplementation on muscle and liver function and muscular strength. J. Sport Leisure Studies 16, 593-605.

\title{
초록 : 8주 유산소 트레이닝이 중년의 제 2형 당뇨(T2DM)환자의 혈청지질 및 신장기능에 미치는 영향
}

\author{
김철우 ${ }^{*}$ 곽이섭 ${ }^{1}$ 김군도 ${ }^{2} \cdot$ 김영일 ${ }^{3} \star$ \\ (1동의대학교 체육학과, ${ }^{2}$ 부경대학교 미생물학과, ${ }^{3}$ 영산대학교 스포츠건강관리학과)
}

본 연구의 목적은 8 주 유산소 트레이닝이 제 2형 당뇨(T2DM)환자의 콜레스테롤과 신장기능에 미치는 영향을 규명하기 위함이다. 피험자는 총 4 명(남 3, 여 1)이며 8 주 유산소 걷기 트레이닝의 운동강도는 최대심박수( $\left.\mathrm{HR}_{\max }\right)$ 의 60 75\%, 주당 3 5 회, 20 45 분간 실시되었으며 다음과 같은 결과를 얻었다. 신체적 특성 중 체지방률과 공복 시 혈당은 8 주 유산소 걷기 트레이닝 후 유의하게 $(p<0.05)$ 감소함을 나타냈고, 혈중지질인 총 콜레스테롤(TC)과 중성지방(TG)도 유의한 감소를 나타냈다. 그러나 신장기능[BUN, uric acids, creatinine]은 유의한 변화를 나타내 지 못했다. 결과적으로 8 주 유산소 트레이닝은 제 2 형 당뇨(T2DM)와 당뇨병성 신증 환자의 1 예에서 체지방률과 공복시혈당, 지질을 감소시키는데 영향을 미쳤지만 신장기능 증진에는 어떠한 영향도 미치지 못했다. 